\title{
ELEMENTAL ANALYSIS AND BIOLOGICAL STUDIES OF PHYSALIS ANGULATA L. USING WAVE LENGTH-DISPERSIVE X-RAY FLUORESCENCE TECHNIQUE, WAVELENGTH DISPERSION X-RAY FLUORESCENCE, FROM RAJASTHAN
}

\author{
RAMAN PREET*, RAGHBIR CHAND GUPTA, SAROJ KUMAR PRADHAN
}

Department of Botany, Punjabi University, Patiala, Punjab, India. Email: ramanbrar247@gmail.com

Received: 06 March 2017, Revised and Accepted: 05 May 2017

ABSTRACT

Ojective: This study is undertaken to identify the total mineral content of both the cytotypes from different plant parts, i.e., fruit, leaf, stem, and roots.

Method: Wavelength dispersion X-ray fluorescence technique is a simple method, recognized as a nondestructive technique to determine the elements from the raw plant material without any chemical treatment and helps to ascertain the nutritional role.

Result: The analysis of mineral content led to the identification and concentration analysis of twenty-seven elements in diploid cytotype and twentyfive in tetraploid cytotype. The percentage value of potassium (5.52\%); iron $(0.50 \%)$ and selenium $(0.0042 \%)$ is reported to be higher in diploid cytotype and the amount of calcium (2.15\%); magnesium $(0.75 \%)$ and zinc $(0.0075 \%)$ are higher in tetraploid cytotype. The analysis of mineral content led to the identification and concentration analysis of twenty-seven elements in diploid cytotype and twenty-five in tetraploid cytotype. The percentage value of potassium (5.52\%); iron $(0.50 \%)$ and selenium $(0.0042 \%)$ is reported to be higher in diploid cytotype and the amount of calcium $(2.15 \%)$; magnesium $(0.75 \%)$ and zinc $(0.0075 \%)$ are higher in tetraploid cytotype. The analysis of mineral content led to the identification and concentration analysis of twenty-seven elements in diploid cytotype and twenty-five in tetraploid cytotype. The percentage value of potassium (5.52\%); iron (0.50\%) and selenium (0.0042\%) is reported to be higher in diploid cytotype and the amount of calcium (2.15\%); magnesium (0.75\%) and zinc $(0.0075 \%)$ are higher in tetraploid cytotype.

Conclusion: The amount of most of the minerals is higher in tetraploid cytotype as compared to the diploid cytotype. This information is very helpful in standardization of herbal products as this plant species is widely used for its medicinal benefits. Tnt of calcium (2.15\%); magnesium (0.75\%) and zinc $(0.0075 \%)$ are higher in tetraploid cytotype..

Keywords: Wavelength dispersion X-ray fluorescence, Medicinal plant, Physalis angulata L, Elemental analysis.

(c) 2017 The Authors. Published by Innovare Academic Sciences Pvt Ltd. This is an open access article under the CC BY license (http://creativecommons. org/licenses/by/4. 0/) DOI: http://dx.doi.org/10.22159/ajpcr.2017.v10i8.18650

\section{INTRODUCTION}

India has a rich experience of using medicinal herbs since old civilizations. A large proportion of world's population depends on medicinal plants as home remedies and nutritional supplements. These plants also act as a raw material for the pharmaceutical industries for the production of various medicines. According to a survey conducted by the World Health Organization (WHO), $80 \%$ of the world's population depends on traditional methods of health care [1]. Plants contain pharmacologically active compounds such as alkaloids, flavonoids, glycosides, and many other important organic compounds. Metallic ions also play a very key role in proper functioning of human body; hence, these are integral components of plants (Marscher 1995; LÜttge et. al., 2010) [2,3].

Human body needs a variety of elements for the proper functioning of all body parts. Physalis angulata L. is one such herb that contains essential and trace elements which are important for proper functioning and growth of human body. Deficiency of these elements causes a wide range of abnormalities and metabolic disorders. Determination of metals in medicinal plants is done to establish their purity, safety, and efficiency. There is no general guideline for the permissible level of the elements in medicinal herb, except only for cadmium $(0.3 \mathrm{mg} / \mathrm{kg})$; arsenic $(1 \mathrm{mg} / \mathrm{kg})$ and lead $(10 \mathrm{mg} / \mathrm{kg})$. The ability of these metals to affect the pharmacological activity of herbs is the most obvious reason to study the amount of these elements in plants. X-ray fluorescence is a rapid and accurate analyzing method involving minimal sample preparation and provides multi-element determination.
Mineral composition of plants, spices, herbs, essential oils, legumes, nuts, yogurts, and vegetables has already been studied. In medicinally important plants and herbs, the content of mineral is already reported by Salamon et al., 2001 [4]; Ražić et. al., 2008, 2005a [5,6]. Mineral content in different stages of fruits of Mespilus germanica was studied by Glew et al., 2002 [7]. Elemental analysis of some medicinal plants from Spain was studied by Queralt et al. [8], in 2005, particularly, from the plants of family Lamiaceae by Ražić et al., 2005b [9]. Metallic mineral elements in a large number of medicinal plants collected from Europe and Mediterranean region and were studied by Chizzola in 2011 [10]. Mineral composition of medicinal plants from Sudan was studied by (Yagi et al., 2013) [11]. In Indian Ayurveda medicinal herbs, minerals were studied by Swamy and Sivanarayanan in 2014 [12]. (Babu et al., 2015) [13] carried out the elemental analysis in some of the important medicinal herbs from India. Recently, elemental analysis of Indian medicinal plants [14] was performed using (EDXRF) technique (Giridhar et al., 2015) [15].

These additional trace elements have influence on pharmacological effects of herbal infusion, so there is need to study the metal content of the plants as there is very narrow range between the deficiency and toxicity of these trace elements in human body as its deficiency causes many diseases and physical disorders. These trace elements are part of our daily food supply and medicines used, so it is of shear important to determine its content, quality and type. There is need to develop simple, rapid and nondestructive method for the analysis of important constituents of plants. wavelength dispersion X-ray fluorescence (WDXRF) is one such method which applies the least destruction to 
the raw plant material as no harsh chemicals are used and give most accurate results. There are many techniques developed for the chemical analyses and determination of elements in plants among them are flame atomic absorption spectrometry, atomic absorption spectrometry (AAS), neutron activation analysis, electrothermal AAS, inductively coupled plasma atomic emission spectrometry (ICP-MS) which are commonly used. However, these techniques usually require chemical treatments $\left(\mathrm{HCL}, \mathrm{H}_{2} \mathrm{SO}_{4}\right.$, and $\mathrm{HNO}_{3}$ ) for the sample preparation like addition of acids (wet ashing) and sometimes involve combination of samples (dry ashing). This chemical treatment leads to errors in results due to contamination. On the other hand, X-ray fluorescence does not require any chemical treatment to the samples, lesser time is required and more accurate results are obtained. These are some of the reasons which make the technique more popular over the past few years.

The amount of various constituents including minerals should vary in different plant parts, stages of meiosis, environmental conditions and genotype particularly with difference in ploidy level. No such studies on elemental analysis in any species on cytotype basis are available.

Medicinal plants contain rich amount of trace elements which increases the curative effect of plants (Singh, 1997) [16]. This technique (WDXRF) is widely used to detect the elements in algae, in tea [17], milk-based products [18], in spices [14], of some plants used as condiments (Özcan, 2004) [19], in medicinal plants [8,20], mineral composition of ten commercially available teas [21], and in potato starch by Noda et al., 2006 [22]. Previously, the mineral content in milk based products [23], in yoghurt [24], in legumes and nuts [25] and in some essential oils [26] was also estimated. Quantitative analysis of eighteen elements was performed using WDXRF technique in plant species [27]. 10 important medicinal plants were determined by Jabeen in 2010 [28] from Pakistan. Quantitative determination of five medicinal plants Oroxylum indicum, Leucas indica, Premna tomentosa, Piper chaba, and Hedychium spicatum were carried out using WD-XRF technique by Swamy and Sivanarayanan in 2014 [12]. Mineral concentration of fruits and leaves of P. angulata L. was studied by Aliero and Usman in 2016 [29]. For all these reasons, this work is undertaken to determine and compare the total elemental content of both the cytotypes of $P$. angulata $\mathrm{L}$.

\section{METHODS}

Wild plant samples were collected from different areas of Rajasthan. Diploid cytotype is collected from Udaipur District and tetraploid cytotype from Sri Ganganagar District of Rajasthan. Fruits, leaves, stem, and roots were removed from the plants and were washed and allowed to dry at room temperature. Dried fruit, stem, leaves, and roots material were grinded using blender. These grinded samples were used in XRF analyses. The powdered sample was pressed to a pellet of $3.5 \mathrm{~cm}$ diameter and $8 \mathrm{~g}$ mass using a 20 ton hydraulic press. The prepared pellets were incubated at $80^{\circ} \mathrm{C}$ for 20 minutes for the removal of all the moisture content.

\section{Instrument parameter}

WDXRF Spectrometer - S8 TIGER.

Elemental coverage - Beryllium (Be) to Uranium (U).

$\mathrm{X}$-ray generation mode - Rhodium target X-ray tube of $4 \mathrm{KW}$.

Rotation speed of sample - $30 \mathrm{rpm}$.

Minimum detection limit - 1 ppm.

\section{RESULTS AND DISCUSSION}

In this study, the percentage of twenty-eight elements in diploid cytotype and twenty-six elements in tetraploid cytotype are determined in fruits, leaves, stems, and roots extracts of $P$. angulata L. collected from different regions of Rajasthan. The anaysized elements in decreasing

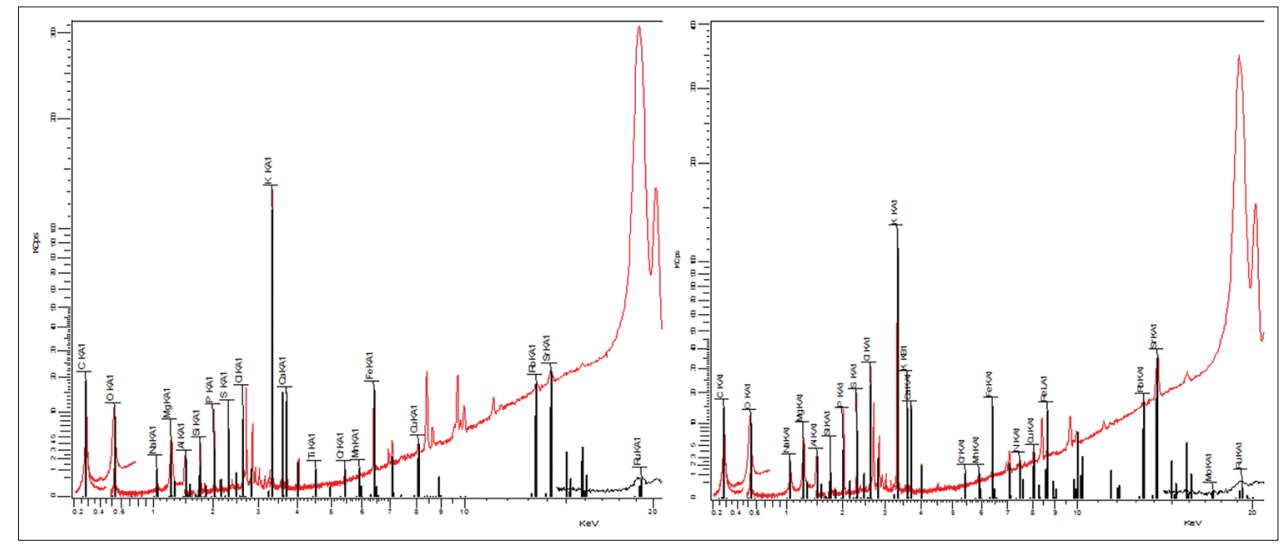

Fig. 1: Wavelength dispersion X-ray fluorescence chromatographs of fruit samples of diploid and tetraploid cytotype of Physalis angulata L.

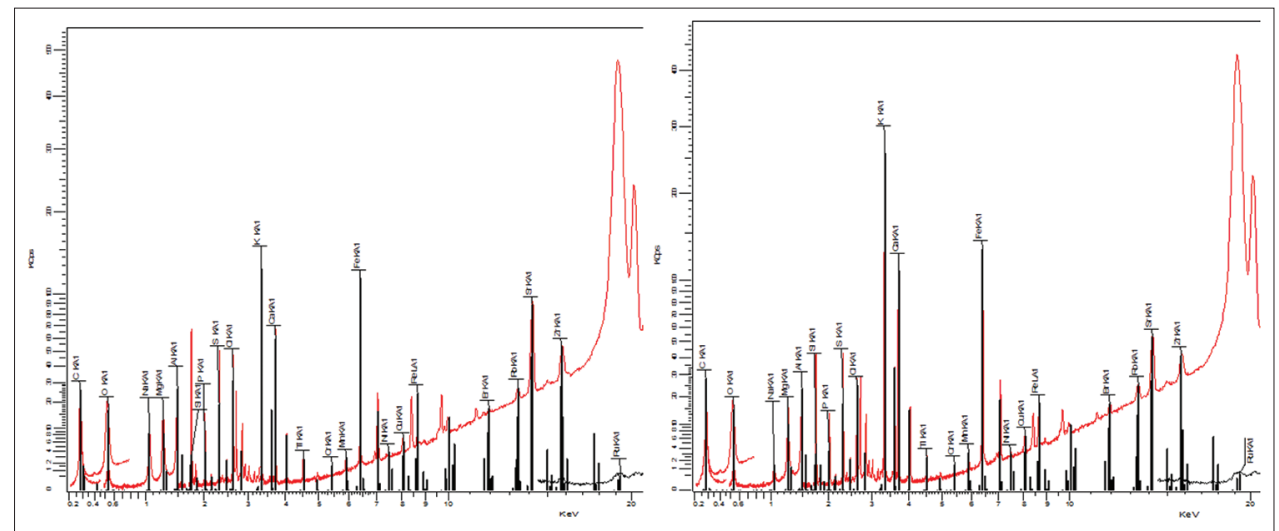

Fig. 2: Wavelength dispersion X-ray fluorescence chromatographs of leaf samples of diploid and tetraploid cytotype of Physalis angulata L. 


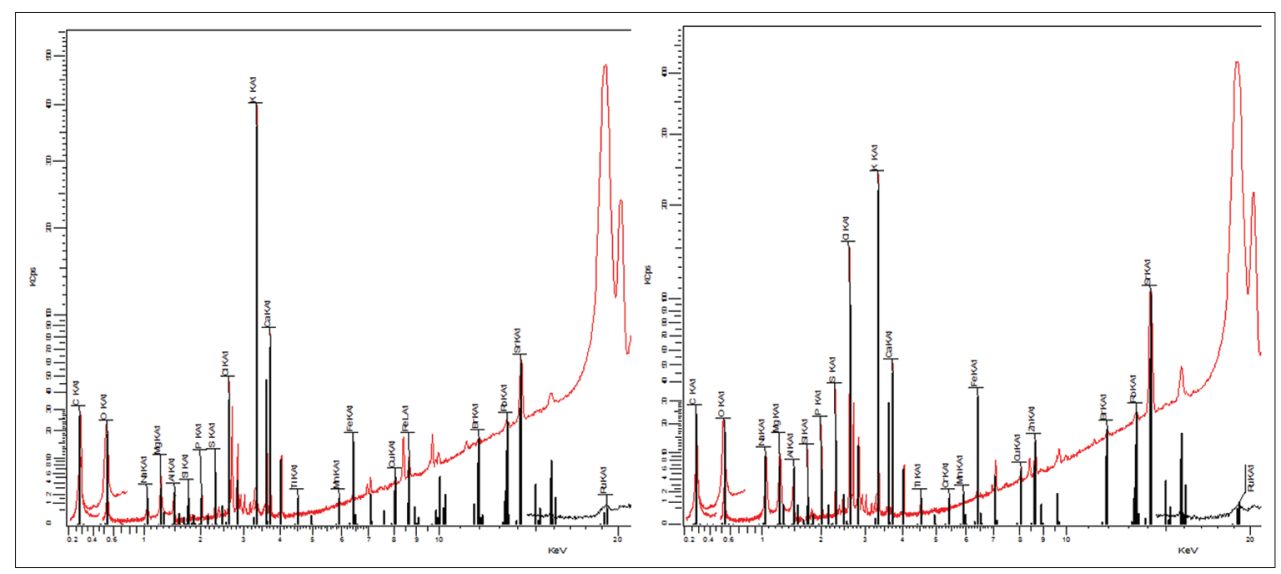

Fig. 3: Wavelength dispersion X-ray fluorescence chromatographs of stem samples of diploid and tetraploid cytotype of Physalis angulata L.

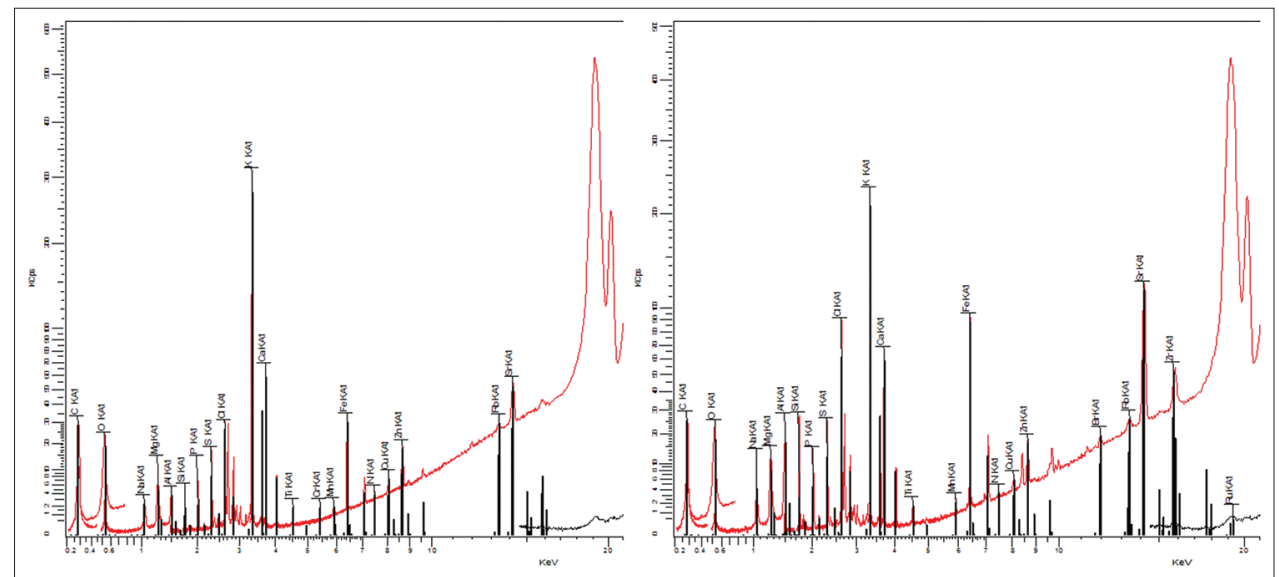

Fig. 4: Wavelength dispersion X-ray fluorescence chromatographs of root samples of diploid and tetraploid cytotype of Physalis angulata L.

Table 1: Data showing comparative analysis of minerals in different plant parts in both the cytotypes of Physalis angulata $\mathrm{L}$.

\begin{tabular}{|c|c|c|c|c|c|c|c|c|c|}
\hline \multirow[t]{2}{*}{ S. No. } & \multirow[t]{2}{*}{ Element } & \multicolumn{2}{|c|}{ Fruit (\%) } & \multicolumn{2}{|c|}{ Leaf (\%) } & \multicolumn{2}{|c|}{ Stem (\%) } & \multicolumn{2}{|c|}{ Root (\%) } \\
\hline & & $2 x$ & $4 x$ & $2 x$ & $4 x$ & $2 x$ & $4 x$ & $2 x$ & $4 x$ \\
\hline 1. & Potassium (K) & 3.11 & 3.42 & 2.32 & 4.44 & 5.52 & 3.99 & 4.18 & 3.48 \\
\hline 3. & Chlorine (Cl) & 0.28 & 1.05 & 1.02 & 0.57 & 0.81 & 2.96 & 0.53 & 1.73 \\
\hline 4. & Magnesium (Mg) & 0.34 & 0.45 & 0.65 & 0.75 & 0.22 & 0.44 & 0.30 & 0.54 \\
\hline 5. & Sodium $(\mathrm{Na})$ & 0.09 & 0.62 & 1.19 & 0.19 & 0.11 & 1.31 & 0.31 & 0.57 \\
\hline 6. & Silicon (Si) & 0.23 & 0.38 & 2.40 & 1.46 & 0.12 & 0.38 & 0.18 & 0.95 \\
\hline 7. & Phosphorus (P) & 0.41 & 0.57 & 0.38 & 0.31 & 0.08 & 0.44 & 0.15 & 0.32 \\
\hline 8. & Sulphur (S) & 0.25 & 0.41 & 0.66 & 0.51 & 0.13 & 0.42 & 0.19 & 0.30 \\
\hline 9. & Aluminum (Al) & 0.07 & 0.09 & 0.50 & 0.45 & 0.04 & 0.11 & 0.06 & 0.31 \\
\hline 10. & Iron $(\mathrm{Fe})$ & 0.05 & 0.06 & 0.50 & 0.37 & 0.04 & 0.08 & 0.06 & 0.22 \\
\hline 11. & Rhenium (Re) & 0.01 & 0.0090 & 0.01 & 0.02 & 0.01 & - & - & - \\
\hline 12. & Strontium (Sr) & 0.0014 & 0.0065 & 0.02 & 0.01 & 0.01 & 0.02 & 0.0057 & 0.03 \\
\hline 13. & Titanium (Ti) & 0.0040 & 0.0054 & 0.03 & 0.03 & 0.0021 & 0.0069 & 0.0034 & 0.02 \\
\hline 14. & Manganese (Mn) & 0.0029 & 0.0018 & 0.0065 & 0.01 & 0.0020 & 0.0038 & 0.0033 & 0.0051 \\
\hline 15. & Copper $(\mathrm{Cu})$ & 0.0016 & 0.0023 & 0.0026 & 0.0037 & 0.0012 & 0.0021 & 0.0033 & 0.0019 \\
\hline 17. & Rubidium (Rb) & 0.0007 & 0.0055 & 0.0015 & 0.0021 & 0.0010 & 0.0010 & 0.009 & 0.0011 \\
\hline 18. & Molybdenum (Mo) & - & 0.0016 & - & - & 0.0012 & - & - & - \\
\hline 19. & Nickel (Ni) & - & 0.0018 & 0.0009 & 0.0008 & - & - & 0.0011 & 0.0007 \\
\hline 20. & Zirconium (Zr) & 0.0002 & 0.0002 & 0.01 & 0.0019 & 0.0002 & 0.0007 & - & 0.0012 \\
\hline 21. & Zinc $(\mathrm{Zn})$ & 0.0001 & 0.0001 & 0.0001 & 0.0001 & 0.0001 & 0.0075 & 0.0093 & 0.01 \\
\hline 22. & Yttrium (Yb) & 0.0032 & & - & & - & & - & - \\
\hline 23. & Chromium (Cr) & 0.0023 & 0.0026 & 0.0018 & 0.0033 & - & 0.0016 & 0.0024 & - \\
\hline 24. & Ruthenium (Ru) & 0.0016 & 0.0017 & 0.0016 & 0.0021 & 0.0021 & 0.0022 & - & 0.0018 \\
\hline 25. & Cerium (Ce) & - & - & 0.0059 & - & - & - & - & - \\
\hline 26. & Lead (Pd) & - & & 0.0022 & - & - & - & 0.0023 & \\
\hline 27. & Bromine (Br) & - & - & 0.0007 & 0.0018 & 0.0006 & 0.0011 & - & 0.0017 \\
\hline 28. & Barium (Ba) & - & - & - & 0.0088 & - & & - & - \\
\hline
\end{tabular}


order in both the cytotypes are listed in Table 1 . The chromatographs are shown in Figs. 1-4.

This study is conducted to study the diversity of mineral composition in two cytotypes of $P$. angulata L. an important medicinal plant. This plant species was collected from different districts of Rajasthan. The populations collected from Udaipur District showed $n=12$, i.e., diploid cytotype and one sample collected from Sri Ganganagar shows n= 24, i.e., tetraploid cytotype. In this results, it is clear that $P$. angulata $\mathrm{L}$. is very rich in mineral content, all the mentioned minerals except iodine, are present in both the cytotypes of the plant species collected from different regions of Rajasthan (Table 1).

The maximum percentage of potassium was found in stem of diploid cytotype $(5.52 \%)$ followed by leaf of the tetraploid cytotype (4.44\%).

Calcium is an essential nutrient that plays a key role in neuromuscular function, blood clotting, it gives rigidity to the skeleton by virtue of its phosphate salt and helps to maintain metabolism of the human body. According to a report by $\mathrm{FAO} / \mathrm{WHO}$, the calcium intake vary from $300 \mathrm{mg}$ to $1200 \mathrm{mg}$ per day depending on the age and physical health of the individual. This plant is a good source of calcium as the amount of the mineral detected in leaf of tetraploid cytotype is $2.15 \%$, and in diploid cytotype, it is maximum in its stem $1.41 \%$ (Fig. 3) (Table 1).

Magnesium is another such mineral which is recommended by WHO. The maximum amount of magnesium is reported in leaves of the tetraploid cytotype $(0.75 \%)$ whereas in diploid cytotype it is $0.65 \%$ (Fig. 2). Magnesium acts as a cofactor for many enzymes involved in energy metabolism, DNA and RNA synthesis, protein synthesis and maintenance of electrical potential of nervous tissues and cell membrane.

Sodium, silicon, phosphorous, and aluminum are some of the elements which are present in variable amount in all the plant parts of this plant species (Table 1).

Iron is a carrier of oxygen from the lungs to the tissues by red blood cells hemoglobin. It is also needed for the development of healthy brain and immune system. Its recommended daily requirement is from 11 to $8 \mathrm{mg}$ per day depending on the age of the person. In P. angulata L. maximum amount of various is reported in leaves of the diploid cytotype $(0.50 \%)$ followed by leaves of the tetraploid cytotype $(0.37 \%)$ (Fig. 2) (Table 1).

Selenium protects the cells and supports immune functions as its works with vitamin $\mathrm{K}$ and also acts as antioxidant. Recommended nutrient intakes of selenium ( $\mu \mathrm{g} /$ day) is $6 \mu \mathrm{g}$ for $0-6$ months to $33 \mu \mathrm{g}$ for adults above 65 years. It is reported in fruits of the diploid cytotype $(0.0042 \%)$ and leaves the tetraploid cytotype (0.0019\%) (Fig. 1) (Table 1).

Zinc is present in all body tissues and fluids. It is an important component of the enzymes which take part in synthesis and degradation of proteins, carbohydrates, lipids, and nucleic acid. It is required for healthy immune system. Its maximum amount is reported in the roots of the tetraploid cytotype $(0.01 \%)$ and $0.0093 \%$ in diploid cytotype) (Fig. 4) (Table 1).

Trace elements play a very significant role in the formation of active constituents responsible for the curative properties in our body, and some of the elements are of vital importance for various metabolic processes, human growth, and overall health [30]. The bioactivity of any plant species is directly related to the chemical composition of the plant species; therefore, it is obvious that if the ploidy of the plant species is different, i.e., diploid and tetraploid then the chemical content of the cytotypes may vary. As in present chase, it is clear that both the cytotypes do not show similar results. The amount of total mineral content is higher in the tetraploid cytotype and lesser in diploid cytotype which makes them chemotypes of the plant. The presence of chemical variation with the cytological variation is very clear from the results.

Studies have been conducted to compare the quality as well as the quantity of minerals in diploid and polyploid genotypes. Most of the studies favor the concept which refers to high content of active constituents in polypoids then in diploids (Bahuhuna et al., 2000 and Berkov 2001) [31,32]. However, it is noteworthy that this is not always the ideal condition the effects of polyploids are not predictable [33], sometimes there is no difference in the diploid and polyploidy of the plant species [34]. The alterations in chemical content of polypolids may result in distorted alterations with other members of the biotic community, such as soil organisms, insect herbivores and hence may have pronounced effects on their [35]. Hence, the amount of minerals is different in different species, plant parts, environmental conditions, and soil conditions.

\section{REFERENCES}

1. Bodeker G, Kronenberg F. A public health agenda for traditional, complementary, and alternative medicine. Am J Public Health 2002;92:1582-91.

2. Marscher H. Mineral Nutrition of Higher Plants. $2^{\text {nd }}$ ed. San Diego: Academic Press; 1995. p. 889

3. LÜttge U, Kluge M, Thiel G. Botanik Die Umfassende Biologie der Pflanzen. Weinheim, Germany: Wiley-VCH; 2010. p. 367-404.

4. Salamon I, Hecl J, Haban M. Heavy metal determination of several medicinal plants in the central Zemplin. In: World Conference on Medicinal and Aromatic Plants, 8-11 July 2001, Budapest, Hungary. Poster PII/47; 2001. p. 187.

5. Ražić S, Dogo S, Slavković L. Investigation on bioavailability of some essential and toxic elements in medicinal herbs. J Nat Med 2008;62:761-7.

6. Ražić S, Onjia A, Dogo S, Slavković L, Popović A. Determination of metal content in some herbal drugs-empirical and chemo-metric approach. Talanata 2005a;67:233-9.

7. Glew RH, Ayaz FA, Vanderjagt DJ, Millson M, Dris R, Niskanen R. A research note mineral composition of medlar (Mespilus germanica) fruit at different stages of maturity. N M J Food Qual 2003;26:441-7.

8. Queralt I, Ovejero M, Carvalho MJ, Marques AF, Llabres JM. Quantitative determination of essential and trace element content of medicinal plants and their infusions by XRF and ICP techniques. X Ray Spectrom 2005;34:213-7.

9. Ražić S, Slavković L, Popović A. Inorganic analysis of herbal drugs. Part I. Metal determination in herbal drugs originating from medicinal plants of family Lamiaceae. J Serbian Chem Soc 2005b;70:1347-55.

10. Chizzola R. Metallic mineral element and heavy metals in medicinal plants. Med Aromatic Plant Sci Biotechnol 2011;6:39-53.

11. Yagi S, Rahman AE, Elhassan GO, Mohammed AM. Elemental analysis of ten Sudanese medicinal plants using x-ray fluorescence. Kounal Appl Ind Sci 2013;1(1):49-53.

12. Swamy GY, Sivanarayanan P. Quantitative determination of essential and trace elements in Indian ayurveda medicinal herbs by WD-XRF spectrometry. Int J Ayurveda Pharm Chem 2014;1:52-62.

13. Babu NG, Srinivasu CC, Raju TP, Das NL. Estimation of trace element concentration in anti-epileptic medicinal plants by using EDXRF. Int J Sci Res 2013;4(2):211-16.

14. Al-Bataina BA, Maslat AO, Al-Kofahi MM. Element analysis and biological studies on ten oriental spices using XRF and Ames test. J Trace Elem Med Biol 2003;17:85-90.

15. Srinivasu CC, Babu NG, Raju TP, Narayana PV, Ram SS, Sudershan $\mathrm{M}$, e al. Concentration of trace elements in selected Indian antidietetic medicinal plants by using EDXRF technique. Int J Rec Sci Res 2016;7(2):9105-8.

16. Singh V, Garg AN. Availability of essential trace elements in ayurvedic Indian medicinal herbs using INNA. Appl Radiat Isot 1997;48(1):97-101.

17. Salvadora MJ, Lopes GN, Filho VJ, Zucchi O. Nascimento quality control of commercial tea by X-ray fluorescence. X Ray Spectrom 2002;31:141-4.

18. Perring L, Andrey D. ED-RF as a tool for rapid minerals control in milk-based products. J Agric Food Chem 2003;51:4207-12.

19. Özcan M. Mineral content of some plants used as condiments in Turkey. Food Chem 2004;84:437-40.

20. Margui E, Hidalgo M, Queralt I. Multielemental fast analysis of 
vegetation samples by wavelength dispersive X-ray fluorescence spectrometry: Possibilities and drawbacks. Spectrochim Acta 2005;60:1363-72.

21. Gallaher RN, Gallaher K, Marshall AJ, Marshall AC. Mineral analysis of ten types of commercially available teas. J Food Compos Anal 2006;19:S53-7.

22. Noda T, Tsuda S, Mori M, Takigawa S, Matsuura-Endo C, Hashimoto N, et al. Determination of the phosphorous content in potato starch using an energy-dispersive X-ray fluorescence method. Food Chem 2006;95:632-7.

23. Perring L, Andrey D. Wavelength dispersive X-ray fluorescence measurements on organic matrices: Application to milk-based products. X Ray Spectrom 2004;33:128-35.

24. Amellal-Chibane H, Benamara S. Total contents of major minerals in the nature yoghurt and in the yoghurts with the date powder of three dry varieties. Am J Food Nutr 2011;1(2):74-8.

25. Cabrera C, Lloris F, Gimenez R, Olalla MM, Lopez C. Mineral content in legumes and nuts: Contribution to the Spanish dietary intake. Sci Total Environ 2003;308:1-14.

26. Knödler M, Lorenz P, Schulz M, Meyer U, Stinzing F. Analysis of toxic heavy metals in selected essential oils. In: VI. Conference on Medicinal and Aromatic Plants, Berlin 19-22 September. Berlin: Humboldt University; 2011. p. 62-3.

27. Krishna AK, Mohan KR, Dasaram B, Murthy NN, Sudarshan V. A qualitative application in quantitative determination of major and trace elements in plant species using wavelength dispersive X-ray fluorescence spectrometry. Atomic Spectrosc 2009;30:208-17.

28. Jabeen S, Shah MT, Khan S, Hayat MQ. Determination of major and trace elements in ten important folk therapeutic plants of Haripur basin, Pakistan. J Med Plant Res 2010;4:559-66.

29. Aliero AA, Usman H. Leaves of ground cherry (Physalis angulata L.) may be suitable in alleviating micronutrient deficiency. Food Sci Technol 2016;4(5):89-94

30. Ptyakowska K, Kita A, Janoska P, Polowniak M, Kozik V. Multielement analysis of mineral and trace elements in medicinal herbs and their infusions. Food Chem 2012;135:494-501.

31. Bahuguna A, Purohit MC, Rawat MS, Purohit A. Qualitative and quantitative variation in alkaloids of Aconitum sps. From Garhwal himalaya. J Plant Biol 2000;27:179-83.

32. Berkov S. Size and alkaloid content of seeds in induced autotetraploids of Datura innoxia, Datura stramonium. Pharm Biol 2001;40:617-21.

33. Evans S. Changing the knowledge base of Western herbal medicine. Soc Sci Med 2008;67(12):2098-106.

34. Wohlmuth H, Leach DN, Smith KK, Myers SP. Gingerol content of diploid and tetraploid clones of ginger (Zingiber officinale Roscoe.). J Agric Food Chem 2005;53(14):5772-3.

35. Hull-Sanders HM, Johnson RH, Owen HA, Meyer GA. Effects of polyploidy on secondary chemistry, physiology, and performance of native and invasive genotypes of Solidago gigantean (Asteraceae). Am J Bot 2009;96(4):762-70. 